\title{
In vitro degradation and antitumor activity of oxime bond-linked daunorubicin-GnRH-III bioconjugates and DNA-binding properties of daunorubicin-amino acid metabolites
}

\author{
Erika Orbán · Gábor Mező · Pascal Schlage · Gabriella Csík · Žarko Kulić • \\ Philipp Ansorge - Erzsébet Fellinger · Heiko Michael Möller · Marilena Manea
}

\begin{abstract}
Bioconjugates with receptor-mediated tumortargeting functions and carrying cytotoxic agents should enable the specific delivery of chemotherapeutics to malignant tissues, thus increasing their local efficacy while limiting the peripheral toxicity. In the present study, gonadotropinreleasing hormone III (GnRH-III; Glp-His-Trp-Ser-His-AspTrp-Lys-Pro-Gly- $\mathrm{NH}_{2}$ ) was employed as a targeting moiety
\end{abstract}

\section{E. Orbán - G. Mező (凶)}

Research Group of Peptide Chemistry, Hungarian Academy of Sciences, Eötvös Loránd University, Pázmány P. stny, 1/A, 1117 Budapest, Hungary

e-mail: gmezo@elte.hu

\section{P. Schlage}

Laboratory of Analytical Chemistry and Biopolymer Structure Analysis, Department of Chemistry, University of Konstanz, Universitätsstrasse 10, 78457 Constance, Germany

\section{Manea ( $\triangle)$}

Laboratory of Analytical Chemistry and Biopolymer Structure Analysis, Department of Chemistry and Zukunftskolleg, University of Konstanz, Universitätsstrasse 10 ,

78457 Constance, Germany

e-mail: marilena.manea@uni-konstanz.de

G. Csik

Department of Biophysics and Radiobiology,

Semmelweis Medical University, Budapest, Hungary

Ž. Kulić - P. Ansorge - H. M. Möller

NMR Spectroscopy, Department of Chemistry,

University of Konstanz, 78457 Constance, Germany

\section{E. Fellinger}

Department of Anatomy, Cell and Developmental Biology, Eötvös Loránd University, 1117 Budapest, Hungary to which daunorubicin was attached via oxime bond, either directly or by insertion of a GFLG or YRRL tetrapeptide spacer. The in vitro antitumor activity of the bioconjugates was determined on MCF-7 human breast and HT-29 human colon cancer cells by 3-(4,5-dimethylthiazol-2-yl)-2,5diphenyltetrazolium bromide assay. Their degradation/ stability (1) in human serum, (2) in the presence of cathepsin $\mathrm{B}$ and (3) in rat liver lysosomal homogenate was analyzed by liquid chromatography in combination with mass spectrometry. The results show that (1) all synthesized bioconjugates have in vitro antitumor effect, (2) they are stable in human serum at least for $24 \mathrm{~h}$, except for the compound containing an YRRL spacer and (3) they are hydrolyzed by cathepsin B and in the lysosomal homogenate. To investigate the relationship between the in vitro antitumor activity and the structure of the bioconjugates, the smallest metabolites produced in the lysosomal homogenate were synthesized and their binding to DNA was assessed by fluorescence spectroscopy. Our data indicate that the incorporation of a peptide spacer in the structure of oxime bond-linked daunorubicinGnRH-III bioconjugates is not required for their antitumor activity. Moreover, the antitumor activity is influenced by the structure of the metabolites (daunorubicin-amino acid derivatives) and their DNA-binding properties.

Keywords Gonadotropin-releasing hormone-III . Oxime bond - Daunorubicin-peptide bioconjugates Antitumor activity - In vitro degradation/stability . DNA binding

\section{Introduction}

A major disadvantage of anticancer drugs is their lack of selectivity for tumor tissues, which causes severe side 
effects and results in low cure rates; therefore, targeted delivery of anticancer drugs is one of the most actively pursued approaches in cancer chemotherapy (Singh et al. 2008). The combination of anticancer drugs with a targeting moiety which recognizes tumor specific or overexpressed receptors on cancer cells might provide efficient chemotherapeutic agents with minimal systemic toxicity (Dubowchik and Walker 1999). Drug delivery systems are generally designed so that the bond between the drug and the targeting moiety is resistant during transport (e.g., in the blood stream, digestive tract), but susceptible to acidic $\mathrm{pH}$ or enzymatic hydrolysis upon internalization into the cancer cells leading to the regeneration of the active cytotoxic agent or to the formation of an active metabolite (Jaracz et al. 2005).

Targeting moieties, such as antibodies (Trail et al. 2003), lectins (Yamazaki et al. 2000), sugars (David et al. 2004), hyaluronic acid (Luo et al. 2002), folic acid (Yadav et al. 2008), peptides (Schally and Nagy 2003) have been employed for the preparation of drug delivery systems for cancer chemotherapy. Tumor targeting with peptides is an intensively investigated approach for the specific delivery of anticancer drugs. It was found that receptors for peptide hormones such as gonadotropin-releasing hormone ( $\mathrm{GnRH})$ and somatostatin are expressed in a higher amount on cancer cells as compared to normal cells and serve as targets for peptide ligands to which cytotoxic drugs can be linked (Schally and Nagy 2004; Mezö and Manea 2010). Consequently, these peptide hormones and their analogs could be used as targeting moieties to deliver cytotoxic agents directly to tumor cells, thereby increasing the concentration of the drugs in the tumor tissue and sparing normal cells from unnecessary exposure. So far, efficient anticancer drug - hormone peptide bioconjugates have been developed in A. V. Schally's laboratory. In these compounds, doxorubicin (Dox) or 2-pyrrolino-doxorubicin were attached through an ester bond to appropriate hormone peptide derivatives that were used as targeting moieties (Schally and Nagy 2003, 2004). The bioconjugates showed high selectivity and significant tumor growth inhibition on many tumor types. However, the fast degradation of the ester bond by carboxylesterases (half life of $2 \mathrm{~h}$ in human serum and 20 min in mouse serum) could lead to an early release of the cytotoxic drug resulting in non-receptor-specific toxicity on rapidly proliferating cells. The main toxic side effect was the myelotoxicity that was more pronounced in case of 2-pyrrolino-Dox (Kovács et al, 2009). Therefore, anticancer drug-peptide bioconjugates having higher stability in human serum are currently being developed. Moreover, increased doses of such compounds could be used to achieve a certain therapeutic effect without toxic side effects.

On the other hand, it has been reported that the intracellular drug release from the bioconjugates is required for their antitumor activity (Malugin et al. 2007). Lysosomes, intracellular organelles that have an internal acidic $\mathrm{pH}(\mathrm{pH}$ 4.8 ) and contain a wide variety of hydrolytic enzymes, play a crucial role in the intracellular drug release. Various spacers/linkers have been developed and employed in the preparation of drug delivery systems for targeted cancer chemotherapy. The most frequently used linkers are (1) hydrazone linker which can be cleaved under acidic conditions in lysosomes, (2) disulfide linkers cleavable inside the tumor cells through disulfide exchange with an intracellular thiol, such as glutathione, (3) peptide linkers designed for high stability in serum and enzymatic hydrolysis in lysosomes (Jaracz et al. 2005).

Examples of peptide spacers cleavable primarily by cathepsin B, a lysosomal enzyme overexpressed in cancer cells, are as follows: -Phe-Lys-, -Val-Cit-, -Gly-Gly-Gly-, -Gly-Leu-Gly-, -Gly-Phe-Leu-Gly-, -Gly-Leu-Phe-Gly- and -Ala-Leu-Ala-Leu- (Dubowchik and Firestone 1998). One of the mostly used spacers is the -Gly-Phe-Leu-Gly- (GFLG) tetrapeptide, which was introduced by Omelyanenko et al. (1998) to connect doxorubicin to HMPA ( $N$-(2-hydroxypropyl)methacrylamide) copolymer. The cleavage of the spacer by cathepsin B allowed the efficient drug release from the biocompatible, but not biodegradable HMPA copolymer (Etrych et al. 2001). In one of our previous studies, a bioconjugate for chemotactic drug targeting was developed, in which the $\gamma$-carboxyl group of methotrexate (Mtx) was attached to an oligotuftsin derivative carrier through the GFLGC pentapeptide spacer (Bai et al. 2008). In the presence of cathepsin $B$, this spacer was completely hydrolyzed resulting mainly in the $\mathrm{Mtx}$ (Gly) metabolite. However, no degradation of the oligotuftsin derivative carrier was observed. When daunorubicin (Dau) was attached via an oxime bond to the aminooxyacetylated GnRH-III derivative [Glp-His-Trp-Ser-His-Asp-Trp-Lys (Aoa-Gly-Phe-Leu-Gly)Pro-Gly- $\mathrm{NH}_{2}$, where Aoa is aminooxyacetic acid], besides the hydrolysis of the tetrapeptide spacer, the $-{ }^{7} \mathrm{Trp}-{ }^{8} \mathrm{Lys}$-peptide bond within the carrier sequence was also cleaved by cathepsin B (Szabó et al. 2009).

The presence of the hydrophobic GFLG spacer in the structure of the above-mentioned Dau-GnRH-III bioconjugate led to decreased solubility in aqueous buffers. Therefore, development of peptide spacers that provide increased solubility to the drug delivery system and are cleavable by lysosomal enzymes is of high importance. It has been reported that cathepsin B has both endopeptidase and peptidyldipeptidase activity; it cleaves C-terminal dipeptides sequentially with a broad specificity. Cathepsin $\mathrm{B}$ also cleaves -Arg-Arg-Xxx-peptide bonds and displays a preference for large hydrophobic residues in the $\mathrm{P} 1^{\prime}$ position (Trp, Tyr, Phe, Leu) and Tyr in the P3 position (Ménard et al. 1993; Taralp et al. 1995). Based on these findings, we designed the -Tyr-Arg-Arg-Leu- tetrapeptide 
spacer and employed it in the preparation of a bioconjugate in which the anticancer drug daunorubicin was attached via oxime bond to the GnRH-III as a targeting moiety.

GnRH-III is a weak GnRH agonist peptide which was first isolated from sea lamprey (Petromyzon marinus) (Sower et al. 1993). It has been shown that it has lower endocrine effect in mammals than the human GnRH (GnRH-I, also called LH-RH), it binds to the GnRH receptors on cancer cells and exhibits antiproliferative effect on many types of $\mathrm{GnRH}$ receptor-positive tumors (Kovács et al. 2007). Chemical modifications of the $\varepsilon$-amino group of Lys in position 8 did not result in a significant change in the antitumor activity of the parent hormone peptide (Mező et al. 1997; Pályi et al. 1999; Herédi-Szabó et al. 2005; Mező et al. 2007). Taking into consideration, these features of the GnRH-III, we prepared drug delivery systems for targeted cancer chemotherapy in which daunorubicin was attached to the side chain of ${ }^{8} \mathrm{Lys}$ of various GnRH-III derivatives. The lack of the hydroxyl group at $\mathrm{C}-14$, which differentiates daunorubicin from doxorubicin, prevents the ester bond formation between the GnRH peptides and the anthracycline derivative. Therefore, in our previous work, daunorubicin was coupled to GnRH-III through an oxime or hydrazone bond (at the $\mathrm{C}-13$ oxo group) resulting in bioconjugates with antitumor activity (Mező et al. 2008; Szabó et al. 2009).

When considering the advantages of the oxime chemical ligation such as (1) easy synthesis due to chemoselectivity and (2) high chemical stability of oxime bond containing bioconjugates, in the present study only oxime bond-linked daunorubicin-GnRH-III bioconjugates were synthesized, structurally and biologically characterized. In addition to the spacer-containing bioconjugates, a compound in which Dau was directly attached to the aminooxyacetylated GnRH-III was prepared, with the aim of investigating whether the incorporation of a spacer is required for the antitumor activity of the bioconjugates. Because the efficacy of these bioconjugates is related to their stability in the blood circulation and to their degradation in the target cells, we investigated the stability/degradation of the bioconjugates (1) in human serum, (2) in the presence of cathepsin B and (3) in rat liver lysosomal homogenate by liquid chromatography in combination with mass spectrometry. The in vitro antitumor activity of the bioconjugates was determined on MCF-7 human breast and HT-29 human colon cancer cells by 3-(4,5-dimethylthiazolyl-2)2,5-diphenyltetrazolium bromide assay (MTT assay). To evaluate the relationship between the in vitro antitumor activity and the structure of the bioconjugates, the smallest metabolites produced in the lysosomal homogenate $(\mathrm{H}-\mathrm{Lys}(\mathrm{Dau}=\mathrm{Aoa})-\mathrm{OH}, \quad$ Dau=Aoa-Gly-OH and $\mathrm{Dau}=$ Aoa-Tyr-OH) were synthesized and their binding to DNA was investigated by fluorescence spectroscopy. The results show that the incorporation of a peptide spacer in the structure of oxime bond-linked daunorubicin-GnRH-III bioconjugates is not required for their in vitro antitumor activity. Moreover, the in vitro antitumor activity of the bioconjugates is influenced by the DNA-binding properties of the smallest metabolites produced in the lysosomal homogenate. Furthermore, in the present study, the $E$-oxime isomer of the bioconjugate without spacer was revealed by NMR spectroscopy.

\section{Materials and methods}

\section{Materials}

All amino acid derivatives for peptide synthesis, benzotriazole-1-yloxytrispyrrolidinophosphonium hexafluorophosphate (PyBOP) and Rink-Amide MBHA resin were purchased from NovaBiochem (Läufelfingen, Switzerland) and GL Biochem Shanghai Ltd (Shanghai, China). Scavengers, coupling agents, and cleavage reagents [triisopropylsilane, 4-methylmorpholine (NMM), piperidine, 1,8-diazabicyclo[5.4.0]undec-7-ene (DBU), trifluoroacetic acid (TFA)] and Boc-aminooxyacetic acid (Boc-Aoa-OH) were obtained from Fluka (Buchs, Switzerland). Daunorubicin hydrochloride was a gift from IVAX (Budapest, Hungary). $N, N$-dimethylformamide (DMF), ethyl acetate (EtOAc) and diethyl ether were from Molar Chemicals Kft (Budapest, Hungary). Hydroxylamine hydrochloride $\left(\mathrm{NH}_{2}-\right.$ $\mathrm{OH} \cdot \mathrm{HCl})$, pentachlorophenol $(\mathrm{PcpOH})$ and solvents for HPLC [methanol $(\mathrm{MeOH})$ and acetonitrile $\left(\mathrm{CH}_{3} \mathrm{CN}\right)$ ] were purchased from Sigma-Aldrich Kft. (Budapest Hungary). 3-(4,5-dimethylthiazol-2-yl)-2,5-diphenyltetrazolium bromide was a Sigma-Aldrich Ltd (St. Louis, MO, USA) product. All reagents and solvents were of analytical grade or highest available purity.

\section{Methods}

\section{Synthesis of oxime bond-linked daunorubicin-GnRH-III bioconjugates}

Aminooxyacetic acid (Aoa) derivatives of GnRH-III ( $<$ EHWSHDWK(Aoa)PG-NH,$\quad<$ EHWSHDWK(AoaGFLG)PG-NH,$\quad<$ EHWSHDWK(Aoa-YRRL)PG-NH ${ }_{2}$, where $\angle E$ is pyroglutamic acid) were prepared manually by solid-phase peptide synthesis according to Fmoc/tBu chemistry on a Rink-Amide MBHA resin $(0.38 \mathrm{mmol} / \mathrm{g}$ coupling capacity). The following Fmoc-protected amino acid derivatives were used: Fmoc-Gly-OH, FmocPro-OH, Fmoc-Lys(Mtt)-OH, Fmoc-Trp-OH, Fmoc$\mathrm{Asp}(\mathrm{O} t \mathrm{Bu})-\mathrm{OH}$, Fmoc-His(Trt)-OH, Fmoc-Ser $(t \mathrm{Bu})-\mathrm{OH}$, Fmoc-Leu-OH, Fmoc-Phe-OH, Fmoc-Tyr $(t \mathrm{Bu})-\mathrm{OH}$ and 
Fmoc-Arg( $(\mathrm{Pbf})-\mathrm{OH}$. The protocol of the synthesis was as follows: (1) DMF washing $(4 \times 1 \mathrm{~min})$, (2) Fmoc deprotection with $2 \%$ DBU, $2 \%$ piperidine in DMF (15 min), (3) DMF washing $(10 \times 1 \mathrm{~min})$, (4) coupling of 5 equiv of Fmoc-amino acid : PyBOP : NMM in DMF (60 min), (5) DMF washing $(4 \times 1 \mathrm{~min})$. Following completion of the synthesis of GnRH-III protected peptide chain, the Mtt protecting group of the ${ }^{8} \mathrm{NH}_{2}$ function of ${ }^{8} \mathrm{Lys}$ was removed by $2 \%$ TFA in DCM and then the peptide-resin was divided into three portions. On one part of the resin, Boc-aminooxyacetic acid was attached to the ${ }^{8} \mathrm{NH}_{2}$ group of ${ }^{8} \mathrm{Lys}$ after pre-activation with PyBOP in the presence of NMM ( 3 equivalent each to the resin capacity; coupling time: $60 \mathrm{~min}$ ). On the second part of the resin, the GFLG tetrapeptide branch was prepared by Fmoc strategy and then Boc-Aoa-OH was attached to the $N$-terminus of the branch as above mentioned. The third portion of the resin was employed for the synthesis of the compound containing the YRRL spacer.

The peptides were cleaved from the resin using a mixture of $95 \%$ TFA, $2.5 \%$ triisopropylsilane and $2.5 \%$ water $(\mathrm{v} / \mathrm{v} / \mathrm{v})$ for $2.5 \mathrm{~h}$ at room temperature and then precipitated with cold diethyl ether, washed three times with diethyl ether and solubilized in $100 \%$ acetic acid prior to freeze drying. The crude products were purified by semi-preparative RP-HPLC and analyzed by mass spectrometry.

The conjugations via oxime bond were carried out in $0.2 \mathrm{M}$ sodium acetate buffer, $\mathrm{pH} 5$, at a peptide concentration of $10 \mathrm{mg} / \mathrm{mL}$. Daunorubicin was used in $20 \%$ excess as compared to the aminooxy derivatives of GnRH-III. The reaction mixtures were stirred for $16 \mathrm{~h}$ at RT and then the bioconjugates were separated by semipreparative RP-HPLC. The purified GnRH-III(Dau=Aoa), 1, GnRH-III(Dau=AoaGFLG), 2 and GnRH-III(Dau=Aoa-YRRL), 3 were characterized by analytical RP-HPLC and mass spectrometry (Table 1 and Electronic Supplementary Material S3-S4).

\section{Synthesis of $\mathrm{H}-\mathrm{Lys}(\mathrm{Dau}=\mathrm{Aoa})-\mathrm{OH}, \mathrm{Dau}=\mathrm{Aoa}-\mathrm{Gly}-\mathrm{OH}$} and Dau=Aoa-Tyr-OH metabolites

Boc-Lys-OH, H-Tyr $(t \mathrm{Bu})-\mathrm{OH}$ or unprotected glycine (1 mmol each) were dissolved in $10 \mathrm{~mL}$ of $2 \mathrm{M} \mathrm{Na}_{2} \mathrm{CO}_{3}$.
Prior to the addition of an equivalent amount of Boc-AoaOPcp in $10 \mathrm{~mL}$ DMF, the solutions were diluted with $10 \mathrm{~mL}$ DMF. The coupling reactions were carried out at $\mathrm{RT}$ for $24 \mathrm{~h}$. The solvents were removed in all cases and the remaining materials were washed with ether to remove the pentachlorophenol. The solid materials were dissolved in water and the $\mathrm{pH}$ was adjusted to 2 with $1 \mathrm{M} \mathrm{HCl}$ under cooling. The protected compounds were extracted with EtOAc, afterwards. The organic solutions were dried over $\mathrm{MgSO}_{4}$ for $1 \mathrm{~h}$, followed by filtration and evaporation of the solvent. The oily compounds were dried in a desiccator for 1 day and then the tert-butyl-type protecting groups were cleaved at RT for $1 \mathrm{~h}$ with TFA containing $5 \%$ d.i. water as a scavenger. The mixtures were concentrated in weighted round bottom flasks using a water aspirator. After that the dried compounds were dissolved in $0.2 \mathrm{M}$ $\mathrm{NH}_{4} \mathrm{OAc}$ ( $\mathrm{pH} \mathrm{5)}$. Daunorubicin hydrochloride (1.5 equiv) was added to the solution of each Aoa-modified amino acid. The oxime ligation was carried out overnight at RT. The reaction mixtures were injected directly to a semipreparative RP-HPLC column to separate the prepared metabolites and the excess of daunorubicin. Except $\mathrm{Dau}=\mathrm{Aoa}-\mathrm{Ty}-\mathrm{OH}$, the conjugates $\mathrm{Dau}=\mathrm{Aoa}-\mathrm{Gly}-\mathrm{OH}$ and $\mathrm{H}-\mathrm{Lys}(\mathrm{Dau}=\mathrm{Aoa})-\mathrm{OH}$ could be well separated $(10 \mathrm{mg}$ crude product was purified in one run). In case of $\mathrm{Dau}=\mathrm{Aoa}-\mathrm{Ty}-\mathrm{OH}$, the compound was dissolved again in $0.2 \mathrm{M} \mathrm{NH}_{4} \mathrm{OAc}(\mathrm{pH} \mathrm{5)}$ and an excess of hydroxylamine hydrochloride was added to this solution. Hydroxylamine reacted with the excess of daunorubicin ( $3 \mathrm{~h}$ reaction time) and then the Dau=Aoa-Tyr-OH and Dau=N-OH could efficiently be separated by RP-HPLC. The synthesized metabolites were characterized by analytical HPLC and mass spectrometry (Table 2 and Electronic Supplementary Material S13).

\section{High-performance liquid chromatography}

Analytical RP-HPLC was performed on a Knauer ( $\mathrm{H}$. Knauer, Bad Homburg, Germany) or on a Dionex system (Dionex, Idstein, Germany) using either a Vydac $\mathrm{C}_{18}$ or a Phenomenex Jupiter $C_{18}$ column $(250 \times 4.6 \mathrm{~mm})$ with

Table 1 Characteristics of oxime bond-linked daunorubicin-GnRH-III bioconjugates

\begin{tabular}{lllr}
\hline Compound number & Code & $\begin{array}{l}\text { RP-HPLC } \\
R_{\mathrm{t}}\left(\mathrm{min}^{\mathrm{a}}\right.\end{array}$ & $\begin{array}{c}\text { ESI-MS } \\
\mathrm{MW}_{\text {calc }} / \mathrm{MW}_{\text {exp }}\end{array}$ \\
\hline 1 & GnRH-III(Dau=Aoa) & 26.5 & $1,840.75 / 1,841.05$ \\
2 & GnRH-III(Dau=Aoa-GFLG) & 29.6 & $2,215.25 / 2,215.45$ \\
3 & GnRH-III(Dau=Aoa-YRRL) & 27.5 & $2,429.11 / 2,429.06$ \\
\hline
\end{tabular}

RP-HPLC profiles and mass spectra are presented in the Electronic Supplementary Material, S3-S4

${ }^{a}$ Column: Vydac $\mathrm{C}_{18}(250 \times 4.6 \mathrm{~mm})$ with $5 \mu \mathrm{m}$ silica $(300 \AA$ pore size); gradient: 0 min $0 \% \mathrm{~B} ; 5 \mathrm{~min} 0 \% \mathrm{~B} ; 50 \mathrm{~min} 90 \% \mathrm{~B} ;$ eluents $0.1 \%$ TFA in water (A) and $0.1 \%$ TFA in acetonitrile-water $(80: 20, \mathrm{v} / \mathrm{v})(\mathrm{B})$; flow rate: $1 \mathrm{~mL} / \mathrm{min}$; detection: $\lambda=220 \mathrm{~nm}$

${ }^{b}$ Bruker Daltonics Esquire $3000+$ ion trap mass spectrometer 
Table 2 Chemical characteristics of daunorubicin and its derivatives

\begin{tabular}{lll}
\hline Compound & $\begin{array}{l}\text { RP-HPLC } \\
R_{\mathrm{t}}(\min )^{\mathrm{i}}\end{array}$ & $\begin{array}{l}\text { ESI-MS } \\
\mathrm{M}_{\text {catc }} / \mathrm{M}_{\text {exp }}^{\mathrm{b}}\end{array}$ \\
\hline Daunorubicin (Dau) & 29.7 & $527.2 / 527.4$ \\
Dau=N-OH & 28.3 & $542.2 / 542.3$ \\
Dau=Aoa-OH $^{\mathrm{c}}$ & 31.6 & $601.2 / 601.2$ \\
Dau=Aoa-Gly-OH & 27.1 & $657.2 / 657.5$ \\
Dau=Aoa-Tyr-OH & 28.7 & $763.3 / 763.5$ \\
H-Lys(Dau=Aoa)-OH & 25.1 & $728.3 / 728.4$ \\
\hline
\end{tabular}

${ }^{a}$ RP-HPLC: column: Phenomenex Jupiter $\mathrm{C}_{18}(250 \times 4.6 \mathrm{~mm}$, $5 \mu \mathrm{m}, 300 \AA$ ); eluents: $0.1 \%$ TFA in water (A), $0.1 \%$ TFA in acetonitrile-water $(80: 20, \mathrm{v} / \mathrm{v})(\mathrm{B})$; flow rate: $1 \mathrm{~mL} / \mathrm{min}$; gradient: $0 \% \mathrm{~B}$ $(0 \mathrm{~min}), 0 \%$ B $(5 \mathrm{~min}), 90 \%$ B $(50 \mathrm{~min})$; detection at $220 \mathrm{~nm}$

b Bruker Daltonics Esquire 3000 + ion trap mass spectrometer

c Dau=Aoa-OH was prepared as previously described (Szabó et al. 2009)

$5 \mu \mathrm{m}$ silica (300 $\AA$ pore size) as a stationary phase. Linear gradient elution $(0 \mathrm{~min} 0 \% \mathrm{~B} ; 5 \mathrm{~min} 0 \% \mathrm{~B} ; 50 \mathrm{~min} 90 \% \mathrm{~B})$ with eluent $A(0.1 \%$ TFA in water) and eluent $B[0.1 \%$ TFA in acetonitrile-water $(80: 20, \mathrm{v} / \mathrm{v})]$ was used at a flow rate of $1 \mathrm{~mL} / \mathrm{min}$. Peaks were detected at $220 \mathrm{~nm}$.

The crude Dau-GnRH-III bioconjugates were purified on a Dionex HPLC system (Dionex, Idstein, Germany) using a semipreparative Vydac $C_{18}$ column $(250 \times 10 \mathrm{~mm})$ with $10 \mu \mathrm{m}$ silica ( $300 \AA$ pore size). Linear gradient elution $(0 \min 10 \% \mathrm{~B} ; 5 \min 10 \% \mathrm{~B} ; 55 \mathrm{~min} 60 \% \mathrm{~B})$ with eluent $\mathrm{A}$ (0.1\% TFA in water) and eluent $B[(0.1 \%$ TFA in acetonitrile-water $(80: 20, v / v)]$ was used at a flow rate of $4 \mathrm{~mL} / \mathrm{min}$. Peaks were detected at 220 and $280 \mathrm{~nm}$. The crude metabolites were purified on a semipreparative Phenomenex Jupiter $\mathrm{C}_{18}$ column $(250 \times 10 \mathrm{~mm})$ with $10 \mu \mathrm{m}$ silica (300 А pore size) using a methanol-water $(90: 10$, v/v) solvent mixture.

\section{Mass spectrometry (MS)}

Electrospray (ESI)-mass spectrometric analyses were carried out on an Esquire $3000+$ ion trap mass spectrometer (Bruker Daltonics, Bremen, Germany). Spectra were acquired in the $100-2,500 \mathrm{~m} / \mathrm{z}$ range. Samples were dissolved in a mixture of $50 \%$ methanol, $48 \%$ water and $2 \%$ acetic acid.

Liquid chromatography-mass spectrometry (LC-MS) was carried out on an Esquire $3000+$ ion trap mass spectrometer (Bruker Daltonics, Bremen, Germany) equipped with an Agilent 1100 HPLC system (Agilent, Waldbronn, Germany). Peptides were separated on a Vydac $\mathrm{MS}_{18}$ column $(150 \times 1 \mathrm{~mm} ; 300 \AA, 3 \mu \mathrm{m})$ using a linear gradient from $90 \%$ solvent $\mathrm{A}[0.1 \%$ formic acid in water (v/v)] and $10 \%$ solvent $B[0.1 \%$ formic acid in acetonitrile $(\mathrm{v} / \mathrm{v})]$ to $70 \%$ solvent $\mathrm{B}$ over $60 \mathrm{~min}$ and a flow rate of $50 \mu \mathrm{L} / \mathrm{min}$. Spectra were recorded in positive ion mode in the $100-2,500 \mathrm{~m} / \mathrm{z}$ range.

\section{Cathepsin B catalyzed hydrolysis of GnRH-III(Dau=Aoa)}

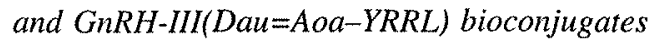

Digestion of GnRH-III(Dau=Aoa) and GnRH-III(Dau= Aoa-YRRL) bioconjugates by cathepsin $\mathrm{B}$ was performed similarly to the digestion of GnRH-III(Dau=Aoa-GFLG) as previously described (Szabó et al. 2009). In brief, the compounds were dissolved at a concentration of $0.1 \mu \mathrm{g} / \mu \mathrm{L}$ in 0.1 M NaOAc buffer containing 0.01 M DTT (pH 5), and then human liver cathepsin B (Calbiochem, Germany; $c=0.4 \mu \mathrm{g} / \mu \mathrm{L}$ in $20 \mathrm{mM} \mathrm{NaOAc}$ buffer, pH 5, containing $1 \mathrm{mM}$ EDTA) was added at an enzyme to substrate ratio of 1:50, w/w. The reaction mixtures were incubated at $37^{\circ} \mathrm{C}$, and aliquots of $20 \mu \mathrm{L}$ were taken after $5 \mathrm{~min}, 2,4,8$ and $24 \mathrm{~h}$ (the reaction was quenched by adding $2 \mu \mathrm{L}$ of acetic acid and followed by LC-MS analysis). A control experiment in which bioconjugate solutions $(c=0.1 \mu \mathrm{g} / \mu \mathrm{L}$ in $0.1 \mathrm{M} \mathrm{NaOAc}$ buffer, pH 5 containing $0.01 \mathrm{M}$ DTT) were incubated at $37^{\circ} \mathrm{C}$ for $24 \mathrm{~h}$ was also performed.

\section{Degradation of daunorubicin-GnRH-III bioconjugates in rat liver lysosomal homogenate}

The rat liver lysosomal homogenate was prepared according to the following procedure: livers from two male rats were collected and homogenized in two volumes of ice cold $0.3 \mathrm{M}$ sucrose with 10 strokes at $15 \mathrm{~g}$. The homogenate was diluted with three volumes of $0.3 \mathrm{M}$ sucrose. The nuclei and cell debris were centrifuged at $700 \mathrm{~g}$ for $10 \mathrm{~min}$. The supernatant was washed with $0.3 \mathrm{M}$ sucrose solution and centrifuged again at $700 \mathrm{~g}$ for $10 \mathrm{~min}$. After that the supernatant was centrifuged at $10,000 \mathrm{~g}$ for $10 \mathrm{~min}$ to sediment the crude lysosomal-mitochondrial fraction. The sediment was re-homogenized in $20 \mathrm{~mL}$ of $0.3 \mathrm{M}$ sucrose containing $\mathrm{CaCl}_{2}$ (final $\mathrm{CaCl}_{2}$ concentration $1 \mathrm{mM}$ ). The homogenate was incubated at $37^{\circ} \mathrm{C}$ for $5 \mathrm{~min}$ for the mitochondria swallowing and then $20 \mathrm{~mL}$ of $50 \%$ Percoll were added to the solution, followed by the centrifugation of the homogenate at $10,000 \mathrm{~g}$ for $10 \mathrm{~min}$. The supernatant was removed, while the pellet was resuspended in $0.3 \mathrm{M}$ sucrose and centrifuged again at $10,000 \mathrm{~g}$ for $10 \mathrm{~min}$. The hard brown pellet was the lysosomal fraction, which was diluted 1:2 with $0.3 \mathrm{M}$ sucrose for the best pipetting.

The protein concentration was determined by Pierce BCA protein assay (bicinchoninic acid) according to the manufacturer's protocol (Thermo Fisher Scientific, Rockford, IL, USA) and it was $16.6 \mu \mathrm{g} / \mu \mathrm{L}$.

The degradation of the daunorubicin-GnRH-III bioconjugates 1,2 and 3 in the rat liver lysosomal homogenate was determined as follows: $100 \mu \mathrm{g}$ of lysosomal homogenate 
was added to $100 \mu \mathrm{g}$ of bioconjugates dissolved in $1 \mathrm{~mL}$ $0.2 \mathrm{M}$ sodium acetate buffer, $\mathrm{pH} 5.0$ (bioconjugates: lysosomal homogenate ratio $=1: 1, \mathrm{w} / \mathrm{w})$. The reaction mixtures were incubated at $37^{\circ} \mathrm{C}$ and aliquots of $50 \mu \mathrm{L}$ were taken at $5 \mathrm{~min}, 1,2,3,4,6,8,24,48$ and $72 \mathrm{~h}$. The reactions were quenched by adding $5 \mu \mathrm{L}$ of acetic acid and followed by LC-MS analysis. Control experiments were performed with solutions of bioconjugates in $0.2 \mathrm{M}$ sodium acetate buffer, pH 5, which were incubated at $37^{\circ} \mathrm{C}$ for 24,48 and $72 \mathrm{~h}$ and then analyzed by LC-MS.

\section{Stability of daunorubicin-GnRH-III bioconjugates in $90 \%$ human serum}

GnRH-III(Dau=Aoa), 1, GnRH-III(Dau=Aoa-GFLG), 2 and GnRH-III(Dau=Aoa-YRRL), 3 were first dissolved in water and then the human serum was added (final peptide concentration $10 \mu \mathrm{M}$ ). The mixtures were incubated at $37^{\circ} \mathrm{C}$. Aliquots of $100 \mu \mathrm{L}$ were taken after $5 \mathrm{~min}, 2,4,8$ and $24 \mathrm{~h}$ in the case of bioconjugates 1 and 2 and after 5 , $10,15,30 \mathrm{~min}, 1,3$ and $6 \mathrm{~h}$ in the case of bioconjugate 3 . The reactions were quenched by adding $10 \mu \mathrm{L}$ of acetic acid. Before mass spectrometric analysis, the larger human serum proteins were removed using Microcon centrifugal devices, cut off $3 \mathrm{kDa}$ (Millipore Corporation, Bedford, MA, USA) and the lower molecular weight fraction was analyzed by LC-MS.

Two control experiments were performed: (1) compounds with molecular weight lower than 3,000 from human serum were separated and analyzed by LC-MS and (2) aqueous solutions of bioconjugates 1,2 and $3(c=10 \mu \mathrm{M})$ were incubated at $37^{\circ} \mathrm{C}$ for $24 \mathrm{~h}$ and then analyzed by LC-MS.

\section{Cells}

MCF-7 human breast adenocarcinoma cells were maintained in DMEM (Sigma Ltd., St. Louis, MO) medium containing $10 \%$ FCS (fetal calf serum, Sigma Ltd.), L-glutamine $(2 \mathrm{mM})$, gentamicin $(160 \mu \mathrm{g} / \mathrm{mL}), 1 \mathrm{mM}$ pyruvate and non-essential amino acids (Sigma Ltd.). HT-29 human colon carcinoma cells were maintained in RPMI-1640 medium containing $10 \% \mathrm{FCS}$, L-glutamine $(2 \mathrm{mM})$ and gentamicin $(160 \mu \mathrm{g} / \mathrm{mL})$. Both cell cultures were maintained at $37^{\circ} \mathrm{C}$ in a humidified atmosphere with $5 \% \mathrm{CO}_{2}$.

In vitro cytostatic effect of bioconjugates determined by 3-(4,5-dimethylthiazol-2-yl)-2,5-diphenyltetrazolium bromide assay (MTT assay)

In vitro cytostatic effect of the bioconjugates was determined by MTT assay (Collins et al. 1977). $5 \times 10^{3}$ cells per well were plated on 96 -well plates. After $24 \mathrm{~h}$ of incubation at $37^{\circ} \mathrm{C}$, cells were treated for $6 \mathrm{~h}$ with the compounds dissolved in serum-free RPMI-1640 medium $\left(2.6 \times 10^{-4}-10^{2} \mu \mathrm{M}\right.$ concentration range $)$. Cells treated for $6 \mathrm{~h}$ with serum-free medium were used as a control. After treatment and incubation, cells were washed twice with serum-free medium and cultured in serum containing medium for $72 \mathrm{~h}$. On the fourth day, the MTT assay was carried out. $45 \mu \mathrm{L}$ MTT solution $(2 \mathrm{mg} / \mathrm{mL}$ ) were added to each well (final concentration $367 \mu \mathrm{g} / \mathrm{mL}$ ) and during $3.5 \mathrm{~h}$ incubation purple crystals were formed by mitochondrial dehydrogenase enzyme present in the living cells. Cells were centrifuged for $5 \mathrm{~min}$ at $863 \mathrm{~g}$ and the supernatant was removed. Crystals were dissolved in DMSO and the optical density (OD) of the samples was determined at $\lambda=540$ and $620 \mathrm{~nm}$ using an ELISA Reader (Labsystems MS reader, Helsinki, Finland). $\mathrm{OD}_{620}$ was subtracted from $\mathrm{OD}_{540}$. The percent of cytostasis was calculated using the following equation:

Cytostasis \% $=\left[1-\left(\mathrm{OD}_{\text {treated }} / \mathrm{OD}_{\text {control }}\right)\right] 100$

where $O D_{\text {treated }}$ and $O D_{\text {control }}$ correspond to the optical densities of treated and control cells, respectively. Cytostasis\% was plotted as a function of concentration fitted to a sigmoidal curve and the $50 \%$ inhibitory concentration $\left(\mathrm{IC}_{50}\right)$ value was determined from these curves (Table 3 ).

\section{Fluorescent properties of daunorubicin, \\ daunorubicin-amino acid derivatives \\ and $\mathrm{GnRH}-\mathrm{III}(\mathrm{Dau}=$ Aoa) bioconjugate}

Ground-state absorption spectra were recorded with $1 \mathrm{~nm}$ steps and $2 \mathrm{~nm}$ bandwidth using a Cary $4 \mathrm{E}$ spectrophotometer (Varian, Mulgrave, Australia). Spectra of Dau and its derivatives were recorded at $10 \mu \mathrm{M}$ concentration (solutions prepared in $20 \mathrm{mM}$ Tris- $\mathrm{HCl}, 50 \mathrm{mM} \mathrm{NaCl}$ buffer, $\mathrm{pH}=7.4$ ). The fluorescence intensity exhibited by the compounds in the absence and in the presence of chicken erythrocyte DNA (Reanal, Hungary) was determined. Fluorescence titration experiments were performed on a FluoroLog ${ }^{\circledR}-3$ spectrofluorometer (Jobin-Yvon, Longjumeau, France) at ambient temperature. Samples were excited at $\lambda=488 \mathrm{~nm}$ and emission spectra were

Table 3 In vitro cytostatic effect of oxime bond-linked daunorubicin-GnRH-III bioconjugates on human MCF-7 and HT-29 cancer cell lines

\begin{tabular}{lll}
\hline Compounds & $\begin{array}{l}\text { Cytostasis } \\
(\mathrm{MCF}-7) \\
\mathrm{IC}_{50}(\mu \mathrm{M})\end{array}$ & $\begin{array}{l}\text { Cytostasis } \\
(\mathrm{HT}-29) \\
\mathrm{IC}_{50}(\mu \mathrm{M})\end{array}$ \\
\hline GnRH-III(Dau=Aoa) & $2.2 \pm 1.2$ & $14.2 \pm 3.2$ \\
GnRH-III(Dau=Aoa-GFLG) & $3.9 \pm 1.2$ & $19.4 \pm 3.1$ \\
GnRH-III(Dau=Aoa-YRRL) & $1.8 \pm 0.5$ & $28.6 \pm 5.5$ \\
\hline
\end{tabular}


recorded between 495 and $800 \mathrm{~nm}$. The ratio of the integrated fluorescence intensity of daunorubicin in the absence of DNA $\left(I_{0}\right)$ and in the presence of DNA $(I)$ was used to calculate the amount of bound compound according to the following equation:

$c_{\text {free }}=c_{\mathrm{t}}\left(I / I_{0}-P\right) /(1-P)$

where $c_{\mathrm{t}}$ is the known added amount of compound and $P$ is the ratio of the observed quantum yield of fluorescence of the totally bound compound to that of the free one; $c_{\text {bound }}$ was then obtained by difference (Chaires et al. 1982). The ratio $P=I_{\infty} / I_{0}$ was obtained from the initial value of $I$ and the plateau value of $I$ at the highest DNA concentration.

\section{Determination of apparent binding constant}

Apparent binding constants were determined by the neighbor exclusion model (McGhee and Von Hippel 1974) using the equation

$$
\frac{r}{c_{\text {free }}}=K(1-n r)\left[\frac{1-n r}{1-r(n-1)}\right]^{n-1} \text {, }
$$

where $r$ is the number of moles of bound compound per mole of DNA base pair, $K$ is the intrinsic binding constant and $n$ is the exclusion parameter in base pairs.

\section{NMR structure analysis}

NMR spectra were acquired at room temperature on a Bruker Avance III $600 \mathrm{MHz}$ spectrometer (Bruker BioSpin $\mathrm{GmbH}$, Rheinstetten, Germany) equipped with a TCI-H/C/N triple resonance cryoprobe. $10 \mathrm{mg}$ of GnRH-III(Dau=Aoa) were dissolved in $\mathrm{H}_{2} \mathrm{O}$ and supplemented with $5 \% \mathrm{D}_{2} \mathrm{O}(\mathrm{v} / \mathrm{v})$. Trimethylsilylpropionic acid-d4 was used as an internal standard. The $\mathrm{pH}$ of the $500 \mu \mathrm{L}$ solution was adjusted to 4 . If applicable, solvent suppression was achieved by excitation sculpting (Hwang and Shaka 1995). 2D NOESY and 2D TOCSY mixing time was 300 and $80 \mathrm{~ms}$, respectively, the latter using the MLEV17 (Bax and Davis 1985) sequence at $8.9 \mathrm{kHz}$ spinlock field strength. Coherence transfer pathways were selected using pulsed field gradients in all experiments. Spectra were processed and analyzed by Bruker Topspin 2.1 and CARA (Keller 2004).

\section{Results and discussion}

Oxime bond-linked daunorubicin-GnRH-III bioconjugates

The concept of targeted cancer chemotherapy based on human GnRH derivatives was introduced by A.V. Schally et al. in the late 1980s (Bajusz et al. 1989). The most promising compound developed by Schally's group, in which doxorubicin-14-O-hemiglutarate was conjugated to the [D-Lys ${ }^{6}$-GnRH-I (AN-152, AEZS-108 (Æterna Zentaris Inc)] (Nagy et al. 1996) is currently in phase II clinical trial on ovarian and endometrial cancer (http://www. aezsinc.com).

However, it has been reported that the ester bond connecting the doxorubicin to the GnRH-I derivative used as a targeting moiety was easily cleaved by carboxylesterases in vitro, in mouse and human sera, resulting in the release of the free drug. The half life time of the bioconjugate was shorter in mouse serum (19.49 $\pm 0.74 \mathrm{~min})$ than in human serum $(126.06 \pm 3.03 \mathrm{~min})$ due to the higher content of carboxylesterases in mouse serum (Nagy et al. 2000). Moreover, toxic side effects were caused by the release of free doxorubicin from the bioconjugate in mice. To elevate the maximum tolerated dose of the ester bond-linked Dox-[D-Lys $\left.{ }^{6}\right]$-GnRH-I bioconjugate, diisopropyl fluorophosphate (DFP) was used in that study to inhibit the activity of the carboxylesterases (CE). In this way, the half life time of the bioconjugate in mouse serum increased to $69.63 \pm 4.44 \mathrm{~min}$.

The major goal of our work was to synthesize, structurally and biologically characterize anthracycline-GnRHIII derivative bioconjugates that have antitumor activity and increased stability in human serum. Taking into consideration that daunorubicin has lower cardiotoxicity than doxorubicin (Gilladoga et al. 1976; Minotti et al. 1995), in the present study, we employed daunorubicin for the preparation of drug delivery systems for targeted cancer chemotherapy. GnRH-III, a weak agonistic hormone peptide with low endocrine effect and own antiproliferative activity was used as a targeting moiety. As already mentioned, because of the lack of $\mathrm{OH}$ group at the C-14 of the aglycon part, daunorubicin was conjugated via oxime bond to the GnRH-III. It has been shown that the acylation of the amino group of daunosamine by GnRH-III peptide resulted in the loss of the antitumor activity (Mezó et al. 2008), therefore, the oxo group at the $\mathrm{C}-13$ position of daunorubicin was used as a conjugation site. An oxime bond was formed between the keto group of daunorubicin and the aminooxyacetyl group of the GnRH-III derivatives. Because the oxime bond is chemically stable between $\mathrm{pH} 3$ and 8 (Shao and Tam 1995), as well as under in vitro and in vivo biological experimental conditions ( $\mathrm{pH}$ 7.4) (Braslawsky et al. 1991), the incorporation of an enzymatic cleavable spacer between the anticancer drug and the targeting moiety might be necessary for the efficient drug release and antitumor activity. In one of our previous studies, the GFLG tetrapeptide spacer cleavable by cathepsin B was incorporated between Dau and GnRH-III leading to the formation of a bioconjugate which had in vitro and in vivo antitumor effect (Szabó et al. 2009). 
When considering that the presence of the hydrophobic GFLG spacer in the structure of the above-mentioned DauGnRH-III bioconjugate led to decreased solubility in aqueous buffers, in the current study, we designed and employed a new YRRL tetrapeptide spacer, which provided increased solubility to the drug delivery system and it was cleaved by cathepsin B. Moreover, we were interested in answering the question whether the presence of an enzymatic cleavable spacer between daunorubicin and GnRH-III is required for the antitumor activity of the bioconjugates. For these purposes, three bioconjugates were synthesized in which daunorubicin was attached via oxime bond to the aminooxyacetylated GnRH-III derivative, either directly or by insertion of a GFLG or YRRL tetrapeptide spacer (Fig. 1). All bioconjugates were purified by HPLC and the purified compounds were analyzed by analytical HPLC and mass spectrometry (Table 1 and Electronic Supplementary Material S3-S4).

Cathepsin B catalyzed hydrolysis of GnRHIII(Dau=Aoa) and GnRH-III(Dau=Aoa-YRRL) bioconjugates

Cathepsin B, a lysosomal enzyme overexpressed in cancer cells (Sibrian-Vazquez et al. 2008), plays an important role in the intracellular digestion of proteins taken up by endocytosis. Its cleavage specificity can be used as a basis for the development of drug delivery systems for targeted cancer chemotherapy that provide controlled intracellular

$$
\begin{aligned}
& \text { Glp-His-Trp-Ser-His-Asp-Trp-Lys-Pro-Gly-NH } \mathrm{N}_{2} \\
& \qquad \mathrm{H}_{2} \mathrm{~N}-\mathrm{O}-\mathrm{CH}_{2}-\mathrm{CO}-\mathrm{X} J
\end{aligned}
$$$$
\text { (c) }
$$

Glp-His-Trp-Ser-His-Asp-Trp-Lys-Pro-Gly- $\mathrm{NH}_{2}$

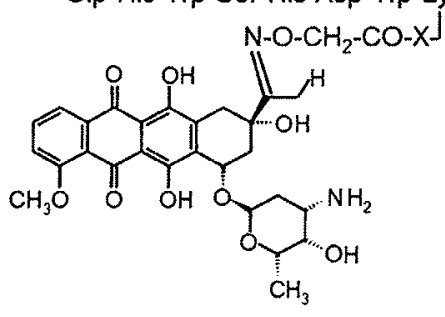

\footnotetext{
$X=\varnothing, G$ nRH-Ill(Dau=Aoa)

$X=G F L G, G \cap R H-1 !(D a u=A o a-G F L G)$

$X=$ YRRL, GnRH-II(Dau=Aoa-YRRL)
}

Fig. 1 Conjugation of daunorubicin to the aminooxyacetylated GnRH-III derivatives drug release (Dubowchik et al. 2002). We have previously shown that the GnRH-III(Dau=Aoa-GFLG) bioconjugate was cleaved by cathepsin B preferentially within the spacer sequence, namely, the peptide bonds -Gly-Phe-, -Phe-Leuand -Leu-Gly-. Furthermore, cleavages of the isopeptide bond -Lys(Gly)- and of the peptide bond- ${ }^{7}$ Trp- ${ }^{8}$ Lys- in the GnRH-III sequence were determined by LC-MS (Szabó et al. 2009).

Incubation of GnRH-III(Dau=Aoa) with cathepsin B, followed by LC-MS analysis of the reaction mixture at different time points, led to the identification of the following cleavage sites: ${ }^{3}{ }^{3}$ Trp- $-{ }^{4}$ Ser-,,$\quad{ }^{4}$ Ser- ${ }^{5}$ His- and ${ }^{7}$ Trp- ${ }^{8}$ Lys- (Fig. 2; Electronic Supplementary Material S5-Fig. 4a). In case of GnRH-III(Dau=Aoa-YRRL) bioconjugate, cathepsin B catalyzed the hydrolysis of -TyrArg-, -Arg-Arg- and -Arg-Leu-peptide bonds within the spacer sequence and of ${ }^{3}$ Trp $-{ }^{4}$ Ser- and $-{ }^{4}$ Ser- ${ }^{5}$ His-peptide bonds in the GnRH-III sequence (Fig. 3; Electronic Supplementary Material S5-Fig. 5b). The fragments resulted after the cleavage of ${ }^{3}$ Trp- ${ }^{4}$ Ser- and ${ }^{-}$Ser- ${ }^{5}$ His-peptide bonds, namely $<\mathrm{EHW}-\mathrm{OH}$ and $<\mathrm{EHWS}-\mathrm{OH}$, formed noncovalent dimers $[<\mathrm{EHW}-\mathrm{OH}]_{2}$ and $[<\mathrm{EHWS}-\mathrm{OH}]_{2}$ that were detected by mass spectrometry at $\mathrm{m} / z 905.40$ $(1+)$ and $1,079.40(1+)$, respectively. No cleavage of the oxime bond was determined after $24 \mathrm{~h}$ incubation at $37^{\circ} \mathrm{C}$ in the presence or absence of the enzyme. Furthermore, in the absence of cathepsin $B$, no cleavage of the peptide bonds was detected (Electronic Supplementary Material S6). It is important to note the fragmentation of the glycosidic bond during the mass spectrometric analysis resulting in the loss of daunosamine $(-129,-147)$, which could not be completely prevented by lowering the capillary exit voltage. Daunosamine and the fragments resulted from the loss of daunosamine were marked in all mass spectra by an asterisk (Electronic Supplementary Material S3-S12).

Degradation of oxime bond-linked daunorubicin-GnRH-III bioconjugates in rat liver lysosomal homogenate

The degradation of GnRH-III(Dau=Aoa), GnRH-III(Dau=Aoa-GFLG) and GnRH-III(Dau=Aoa-YRRL) bioconjugates was also investigated in rat liver lysosomal homogenate. Analyses of the reaction mixtures after $8 \mathrm{~h}$ are presented in the Electronic Supplementary Material S7-S8, in which the LC-ESI-mass spectra summed over the chromatographic window where the compounds eluted are shown. Six cleavage sites were identified in case of GnRH-III(Dau=Aoa) bioconjugate: $\quad{ }^{2} \mathrm{His}^{3} \mathrm{Trp}-$, $-{ }^{4}$ Ser- ${ }^{5}$ His-, $\quad{ }^{6}$ Asp- ${ }^{7}$ Trp-, $\quad{ }^{7}$ Trp- ${ }^{8}$ Lys-, $\quad-{ }^{8}$ Lys- ${ }^{9}$ Pro- and $-{ }^{9}$ Pro- ${ }^{10} \mathrm{Gly}$-. All these cleavage sites were located in the GnRH-III sequence and no cleavage of the oxime bond was 
Fig, 2 Cleavage sites and the corresponding fragments produced by the proteolysis of GnRH-III(Dau=Aoa) cathepsin B (full-line arrows) and rat liver lysosomal homogenate (dotted-line arrows) bioconjugate in the presence of

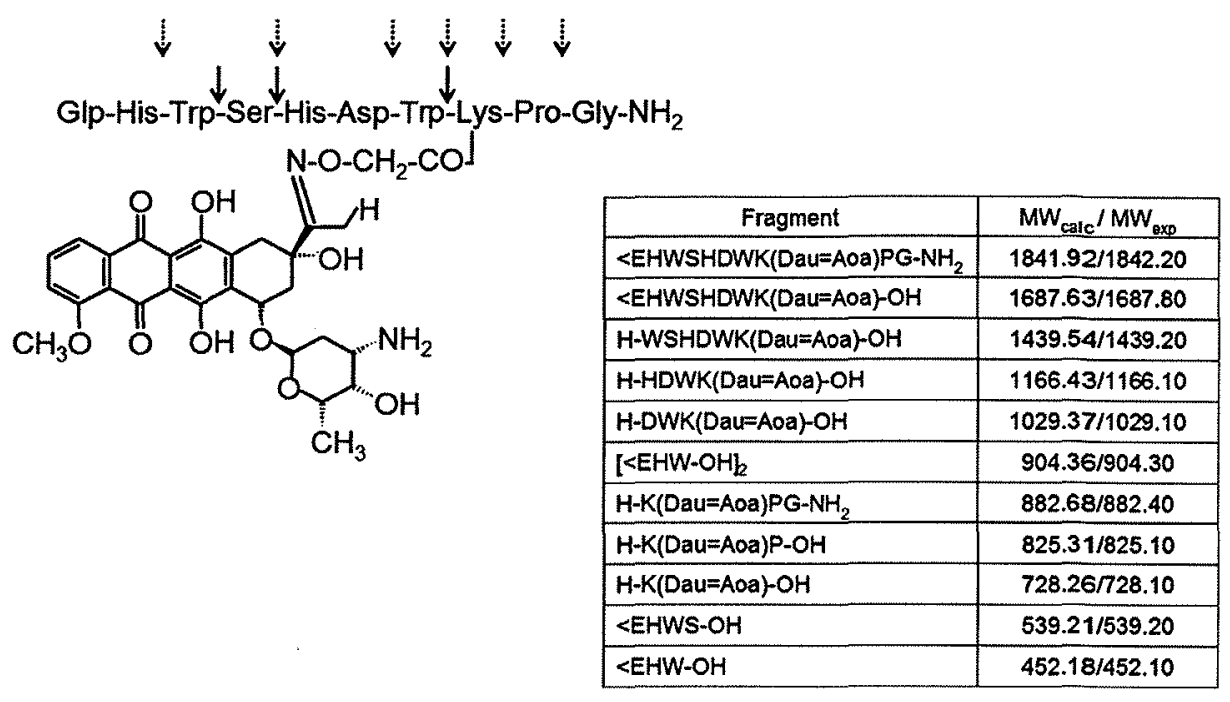

Fig. 3 Cleavage sites and the corresponding fragments produced by the proteolysis of GnRH-III(Dau=Aoa-YRRL) bioconjugate in the presence of cathepsin B (full-line arrows), rat liver lysosomal homogenate (dotted-line arrows) and human serum (dashed-line arrows)

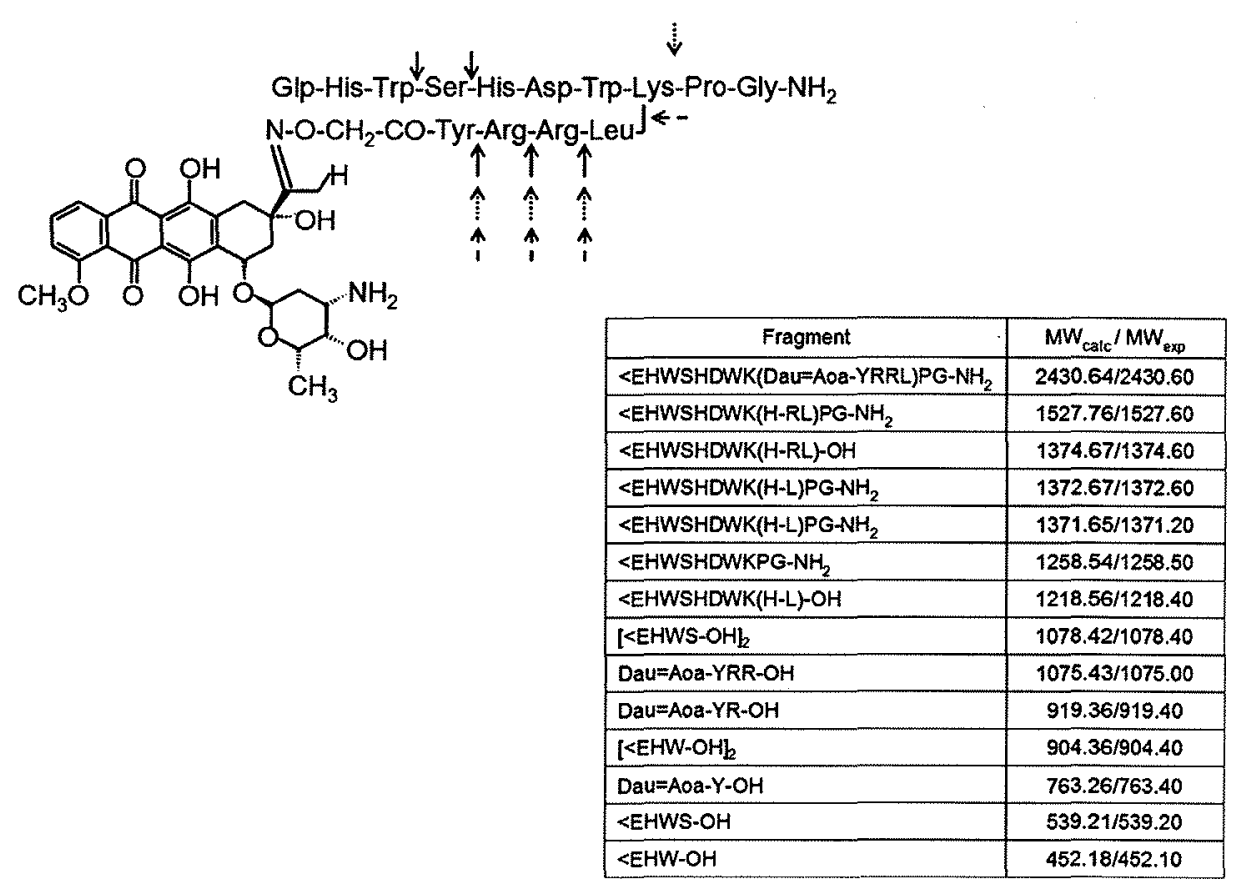

detected (Fig. 2, Electronic Supplementary Material S7Fig. 6a). The smallest fragment containing daunorubicin was identified at $\mathrm{m} / \mathrm{z} 729.1(\mathrm{l}+)$ and it was H-Lys (Dau=Aoa) $-\mathrm{OH}$.

In contrast to GnRH-III(Dau=Aoa), the degradation pattern of the bioconjugates containing a tetrapeptide spacer between Dau and GnRH-III was different. LC-MS analysis of GnRH-III(Dau=Aoa-YRRL) incubated for $8 \mathrm{~h}$ with the rat liver lysosomal homogenate led to the identification of (1) cleavage sites within the spacer sequence (-Tyr-Arg-, -Arg-Arg- and -Arg-Leu-) and (2) cleavage of ${ }_{-8}^{8}$ Lys- ${ }^{9}$ Pro-peptide bond in the GnRH-III sequence (Fig. 3; Electronic Supplementary Material S7 Fig. 6b). Several metabolites containing daunorubicin were produced, the smallest one being Dau=Aoa-Tyr-OH fragment $[\mathrm{m} / \mathrm{z} 764.2$ $(1+)$ and $382.6(2+)]$.

A similar degradation pattern, shown in Fig. 4 and Electronic Supplementary Material S8-Fig. 6c, was obtained in case of GnRH(Dau=Aoa-GFLG). The spacer sequence was primarily hydrolyzed in the presence of lysosomal enzymes (-Gly-Phe-, -Phe-Leu- and -Leu-Gly-); however, the cleavage of the $-^{7}{ }^{7}$ rp $^{-}{ }^{8}$ Lys- and $-{ }^{8}$ Lys- ${ }^{9}$ Propeptide bonds within the GnRH-III sequence was also identified. In this case, Dau=Aoa-Gly-OH was the smallest metabolite containing daunorubicin $[\mathrm{m} / \mathrm{z} \quad 658.1(1+)]$ which was produced. 
Fig. 4 Cleavage sites and the corresponding fragments produced by the proteolysis of GnRH-III(Dau=Aoa-GFLG) bioconjugate in the presence of cathepsin B (full-line arrows) and rat liver lysosomal homogenate (dotted-line arrows)

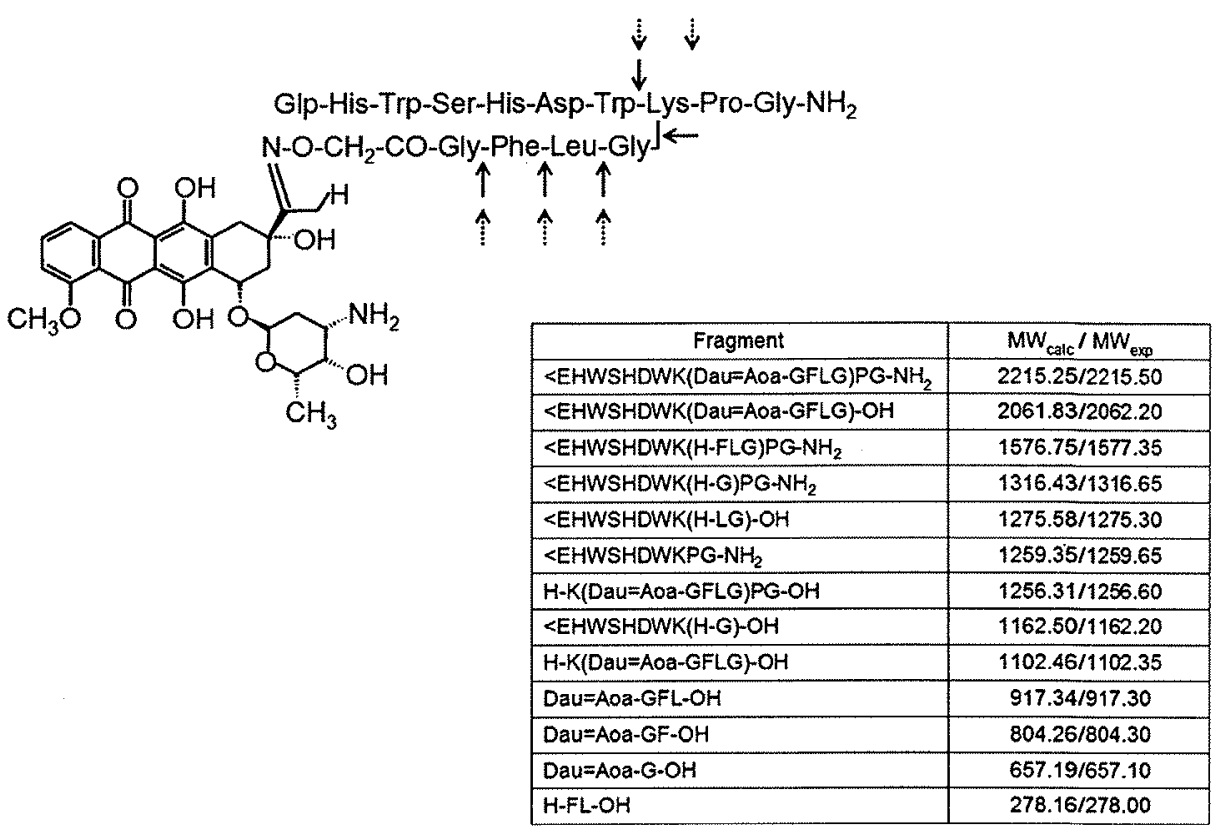

For all three bioconjugates, no additional fragments were identified after longer incubation times, 24-72 h (Electronic Supplementary Material S9, S10).

Stability/degradation of daunorubicin-GnRH-III bioconjugates in human serum

The stability of daunorubicin-GnRH-III bioconjugates in 90\% human serum was determined by LC-MS. GnRHIII(Dau=Aoa) and GnRH-III(Dau=Aoa-GFLG) were stable in human serum at least for 1 day. LC-MS analysis of the bioconjugates incubated for $24 \mathrm{~h}$ at $37^{\circ} \mathrm{C}$ with human serum revealed the presence of intact compounds $(\mathrm{m} / \mathrm{z}$ $921.8(2+), 614.9(3+)$ in case of GnRH-HII(Dau=Aoa) and $\mathrm{m} / \mathrm{z} \quad 1,108.9(2+), 739.7(3+)$ in case of GnRH-III(Dau=Aoa-GFLG); see Electronic Supplementary Material S11) and did not result in the identification of degradation products.

In contrast to GnRH-III(Dau=Aoa) and GnRH-III(Dau= Aoa-GFLG), GnRH-III(Dau=Aoa-YRRL) compound was very fast degraded in human serum. After $5 \mathrm{~min}$ of incubation with human serum at $37^{\circ} \mathrm{C}$, the cleavage of the -Arg-Arg- peptide bond within the spacer sequence was identified by mass spectrometry [resulted peptide fragments: <EHWSHDWK(H-RL)PG-NH 2 at $\mathrm{m} / z \quad 510.30$ $(3+), 383.10(4+)$ and Dau=Aoa-YR-OH at $\mathrm{m} / z 919.30$ $(1+)]$. The intact bioconjugate could be detected in the reaction mixture after $1 \mathrm{~h}$, but not after $3 \mathrm{~h}$. The LC-MS analysis of the aliquot taken out from the reaction mixture after $3 \mathrm{~h}$ led to the identification of the following cleavage sites: -Arg-Arg-, -Tyr-Arg-, -Arg-Leu-peptide bonds and
-Lys(Leu)- isopeptide bond (Fig. 3; Electronic Supplementary Material S12).

In vitro cytostatic effect of daunorubicin-GnRH-III bioconjugates

In vitro cytostatic effect of GnRH-III(Dau=Aoa), GnRHIII(Dau=Aoa-GFLG) and GnRH-III(Dau=Aoa-YRRL) bioconjugates was determined on human MCF-7 and HT29 cancer cell lines by MTT assay and the calculated $\mathrm{IC}_{50}$ values were presented in Table 3 . All investigated compounds had antitumor activity, which was higher on MCF7 cells compared with HT-29. However, no significant difference was observed between the cytostatic effect of the compounds with or without spacer. On MCF-7 cells, $\mathrm{IC}_{50}$ values of all compounds were between 1 and $5 \mu \mathrm{M}$. On HT-29 cells, GnRH-III(Dau=Aoa) was the most effective bioconjugate $\left(\mathrm{IC}_{50}=14.2 \pm 3.2 \mu \mathrm{M}\right)$ and GnRH-III(Dau=Aoa-GFLG) had higher cytostatic effect $\left(\mathrm{IC}_{50}=19.4 \pm 3.1 \mu \mathrm{M}\right)$ compared with GnRH-III(DauYRRL) $\left(\mathrm{IC}_{50}=28.6 \pm 5.5 \mu \mathrm{M}\right)$. Possible explanations of these results might be the higher number of GnRH receptors on MCF-7 cells (Mezó et al. 2008) and/or the different intracellular route of the compounds in HT-29 cells compared to MCF-7 cells (Herédi-Szabó et al. 2006).

The $\mathrm{IC}_{50}$ values of the bioconjugates are one order of magnitude higher on both cell lines than those determined for the free daunorubicin. We have previously shown that daunorubicin was taken up in a much higher amount by cells than the bioconjugates (Szabó et al. 2009). The difference between the $I_{50}$ values of free Dau and 
Dau-GnRH-III bioconjugates could be explained by their differential cellular uptake. Another explanation could be provided by the binding of various metabolites to DNA.

In the present work, we showed that the degradation of bioconjugates in the presence of cathepsin B or in lysosomal homogenate resulted in different metabolites $(\mathrm{H}-$ Lys(Dau=Aoa) $-\mathrm{OH}$ in case of 1 , Dau=Aoa-Gly-OH from 2 , and Dau=Aoa-Tyr-OH from 3) that could influence the biological activity, such as the binding to DNA.

Synthesis of daunorubicin-amino acid derivatives

To investigate the binding to DNA of the smallest metabolites produced in lysosomal homogenate, H-Lys(Dau= Aoa) $-\mathrm{OH}, \quad \mathrm{Dau}=\mathrm{Aoa}-\mathrm{Gly}-\mathrm{OH}$ and $\mathrm{Dau}=\mathrm{Aoa}-\mathrm{Ty} \mathrm{r}-\mathrm{OH}$ were synthesized (Fig. 5). Boc-Aoa-OPcp prepared in our laboratory (Mező et al. 2010) was used to functionalize the amino acids for further oxime ligation. During the coupling reactions, the carboxyl groups of the amino acids were protected as sodium salts. The coupling occured with good yield in case of glycine; however, the application of tyrosine without protecting the phenolic hydroxyl group resulted in side products. Therefore, the hydroxyl group was protected with tert-butyl group that could be removed simultaneously with the Boc protecting group of Aoa. For the synthesis of $\mathrm{H}-\mathrm{Lys}(\mathrm{Aoa})-\mathrm{OH}$, Boc-Lys-OH was used. Considering that the Aoa-containing derivatives are highly sensitive to aldehydes and ketones (Buré et al. 2000), the compounds were used in the reaction with daunorubicin immediately after removing the tert-butyl-type protecting groups. Oxime bond-linked Dau-amino acid derivatives could be well separated from the excess of free Dau, except for Dau=Aoa-Tyr-OH. However, when free Dau was modified by hydroxylamine, the resulted $\mathrm{Dau}=\mathrm{N}-\mathrm{OH}$ could be removed from Dau=Aoa-Tyr-OH by RP-HPLC using methanol-water solvent mixture. It has to be mentioned that Dau $=\mathrm{N}-\mathrm{OH}$ was not stable in the eluent system used for purification $(0.1 \% \mathrm{TFA} /$ methanol-water) and that the free Dau was released in time under acidic conditions and it could be recovered.<smiles>COc1cccc2c1C(=O)c1c(O)c3c(c(O)c1C2=O)C[C@@H](C(C)=NOCC(=O)O)[C@H](O[C@H]1C[C@H](N)[C@H](O)[C@H](C)O1)[C@H]3O</smiles>

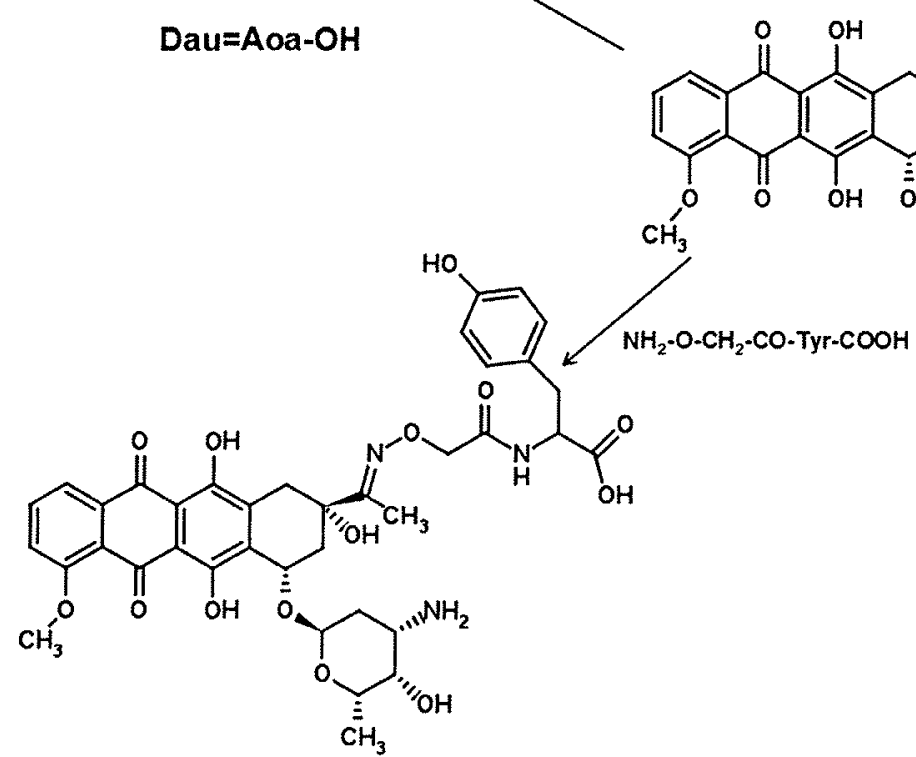

Dau=Aoa-Tyr-OH<smiles>COc1cccc2c1C(=O)c1c(O)c3c(c(O)c1C2=O)C[C@@](O)(/C(C)=N/OCC(=O)NCC(=O)O)C[C@H]3O[C@H]1C[C@H](N)[C@@H](O)[C@H](C)O1</smiles>

Dau=Aoa-Gly-OH 
Determination of apparent binding constants of daunorubicin and its derivatives

The interaction of daunorubicin with DNA is thought to be a crucial step in the molecular mechanism by which it inhibits the DNA replication (Barcelo et al. 1988). The binding of daunorubicin to DNA is most appropriately described by the neighbor exclusion model of McGhee and Von Hippel (1974), taking into consideration the apparent non-linearity in binding isotherms. This model provides an analytical expression which may conveniently be used to extract the binding constant and exclusion parameter from the experimental data. We determined the apparent binding constants $(K)$ of Dau and its derivatives and the data were presented in Table 4 . It is known that the binding constant of daunorubicin is influenced by the ionic strength of the environment and the base composition of the nucleic acid (Chaires 1990).

It is important to note that in some cases, at low binding ratios, our experimental points deviated from the fit obtained by the non-cooperative model. A similar phenomenon was observed by Graves and Krugh (1983) using a phase partition method, when reported positive cooperativity at low binding ratios for the interaction of daunorubicin with calf thymus DNA. In the present work, we cannot answer this question; however, we are aiming the detailed investigation later.

A direct relationship between the affinity toward nucleic acids and biological activity of Dau was established (Valentini et al. 1985). In other instances, there were many deviations and a direct simple correlation between binding parameters and biological activity could not be obtained (Krohn 2008).

The $K$ of free Dau determined here $(K=11.7 \times$ $10^{5} \mathrm{M}^{-1}$ ) is in good agreement with the $K$ values previously obtained (Barcelo et al. 1988) under similar experimental conditions $\left(K=9.0 \times 10^{5} \mathrm{M}^{-1}\right.$ and $K=25.0 \times$ $10^{5} \mathrm{M}^{-1}$ in 100 and $50 \mathrm{mM} \mathrm{NaCl}$ solutions, respectively). Free Dau showed the highest binding to DNA. GnRH-III (Dau=Aoa) could not bind very well to DNA

Table 4 Apparent equilibrium binding constants $(K)$ and the exclusion parameters $(n)$ of daunorubicin and its derivatives on chicken erythrocyte DNA

\begin{tabular}{lcc}
\hline Compound & $K\left(\times 10^{5}\right)\left(\mathrm{M}^{-1}\right)$ & $n$ \\
\hline Dau & 11.7 & 2.5 \\
H-Lys(Dau=Aoa)-OH & 6.80 & 3 \\
Dau=Aoa-Gly-OH & 6.74 & 3.5 \\
Dau=Aoa-OH & 2.21 & 3.8 \\
Dau=Aoa-Tyr-OH & 4.40 & 3.5 \\
GnRH-III(Dau=Aoa) & 0.83 & 4.2 \\
\hline
\end{tabular}

( $K=0.83 \times 10^{5} \mathrm{M}^{-1}$ ), result which could be explained by the size and conformation of the bioconjugate. According to the mass spectrometric analysis, various metabolites are formed in the lysosomal homogenate and these metabolites should bind to the DNA and not necessarily the whole bioconjugate. Our data show that all metabolites could bind to DNA better than the bioconjugate and there was no significant difference between the DNA-binding properties of H-Lys(Dau=Aoa)-OH $(K=$ $\left.6.80 \times 10^{5} \mathrm{M}^{-1}\right)$ and Dau=Aoa-Gly-OH $(K=6.74 \times$ $10^{5} \mathrm{M}^{-1}$ ). The DNA-binding properties of the two metabolites might explain the similar in vitro cytostatic effect of the parent bioconjugates. Interestingly, the $\mathrm{Dau}=\mathrm{Aoa}-\mathrm{OH}$ which was not found as a metabolite in our experiment showed much lower binding to DNA ( $K=$ $2.21 \times 10^{5} \mathrm{M}^{-1}$ ). These results suggest that the distance between Dau and a free carboxyl group might be important for an effective binding to DNA.

Cellular uptake and in vitro cytostatic effect of daunorubicin, daunorubicin-amino acid derivatives and GnRH-III(Dau=Aoa) bioconjugate on MCF-7 cells

We were also interested in determining the in vitro cytostatic effect of the Dau-amino acid derivatives. However, the $\mathrm{IC}_{50}$ values determined by MTT assay would be relevant only in case of a similar (rather identical) uptake of the compounds by the cells. Therefore, the cellular uptake of daunorubicin, daunorubicin-amino acid derivatives and GnRH-III(Dau=Aoa) bioconjugate by MCF-7 cells was investigated by flow cytometry and expressed as the percent of Dau-positive cells. In the Electronic Supplementary Material, S14-S16, the in vitro cytostatic effect and cellular uptake of the compounds are presented. When considering that the cellular uptake of Dau-amino acid derivatives by MCF-7 cells is different, the $\mathrm{IC}_{50}$ values determined by MTT assay cannot be compared.

\section{NMR structure analysis}

In our previous work, the $E$-oxime isomer in a simple model compound, Dau=Aoa-OH, was determined by NMR spectroscopy (Szabó et al. 2009). However, the influence of the peptide chain on the structure has not been investigated yet. Therefore, in the present study, the GnRH-III (Dau=Aoa) bioconjugate was subjected to NMR spectroscopic analysis.

A nearly complete assignment was achieved by combining 2D homonuclear (COSY, TOCSY and NOESY) and heteronuclear $\left({ }^{13} \mathrm{C}-{ }^{1} \mathrm{H}-\mathrm{HSQC},{ }^{13} \mathrm{C}-{ }^{1} \mathrm{H}-\mathrm{HMBC}\right.$ and ${ }^{15} \mathrm{~N}-{ }^{1} \mathrm{H}-$ HSQC) experiments (Fig. 6b-d; chemical shifts are shown in Table 2 in the Electronic Supplementary Material, S17). All $\mathrm{NH}, \mathrm{CH}, \mathrm{CH} 2$, and $\mathrm{CH} 3$ groups were assigned. 
Fig. 6 NMR structure analysis of GnRH-III(Dau=Aoa) bioconjugate. a Numbering of atoms used for NMR assignments (arbitrary), b assigned ${ }^{15} \mathrm{~N}-{ }^{1} \mathrm{H}-\mathrm{HSQC}$ spectrum of GnRH-III(Dau=Aoa) bioconjugate. The side chain amide proton of $\mathrm{Lys}^{8}\left(\mathrm{~K}^{8} \mathrm{sc}\right)$ is stabilized by the isopeptide bond with the daunorubicin-aminooxyacetyl group, c assigned TOCSY spectrum of GnRH-III(Dau=Aoa) bioconjugate in the region of backbone amides, $\mathbf{d}$ intense NOE signals between the amide and aromatic protons (direct dimension) and aliphatic protons (indirect dimension) imply a non-covalent oligomerization of the bioconjugate

Diastereotopic groups were not assigned stereospecifically. Some quaternary carbons of the anthracycline scaffold could not be unambiguously assigned from the HMBC spectra. Their chemical shifts were obtained by comparison with the published data of daunorubicin (Kim et al. 2000).

The $E$-oxime isomer was assigned by the upfield-shifted carbon signal of C-14 (12.86 ppm). The signal would be expected at around 16-17 ppm in a Z-oxime isomer (Parthiban et al. 2008). Interestingly, the bioconjugate exhibited quite intense NOEs (Fig. 6d), implying a noncovalent oligomerization under the employed experimental conditions. Thus, the identified NOEs could correspond to both intramolecular and intermolecular proximities of protons.

The vicinal $\mathrm{H}^{\mathrm{N}}-\mathrm{H}^{\alpha}$-couplings of the peptide backbone range between 4.3 and $9.4 \mathrm{~Hz}$ (Table 2 in the Electronic Supplementary Material). A number of these couplings indicate conformational averaging and suggest, therefore, that the bioconjugate does not adopt a rigid structure; however, three $\mathrm{H}^{\mathrm{N}}-\mathrm{H}^{\alpha}$-couplings $\geq 8 \mathrm{~Hz}$ indicate a preference for an extended, $\beta$-sheet-like structure of the peptide.

\section{Conclusions}

In our study, gonadotropin-releasing hormone-III was employed as a targeting moiety to which daunorubicin was attached via oxime bond, either directly or by insertion of a GFLG or YRRL tetrapeptide spacer, leading to the formation of drug delivery systems for targeted cancer chemotherapy.

Two of the investigated bioconjugates, GnRH-III (Dau=Aoa) and GnRH-III(Dau=Aoa-GFLG), were found to have increased stability in human serum (at least for $24 \mathrm{~h}$ ), whereas the bioconjugate containing the YRRL tetrapeptide spacer was degraded within $3 \mathrm{~h}$. In the presence of both cathepsin B and lysosomal homogenate, all bioconjugates were decomposed; however, no free daunorubicin was released. Using LC-MS, different metabolites were identified in which the aminooxy derivative of Dau was connected to the $\alpha$-amino group of Gly or Tyr or to the $\varepsilon$-amino group of Lys. All three bioconjugates had in vitro antitumor effect on MCF-7 human breast and HT-29 human colon cancer cell lines. However, their antitumor a

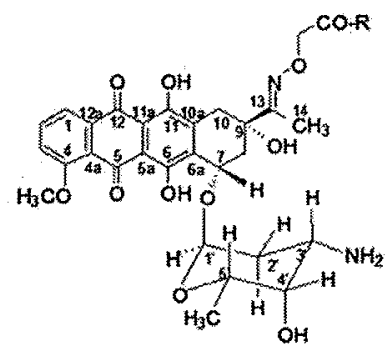

$R=G n R H+11$
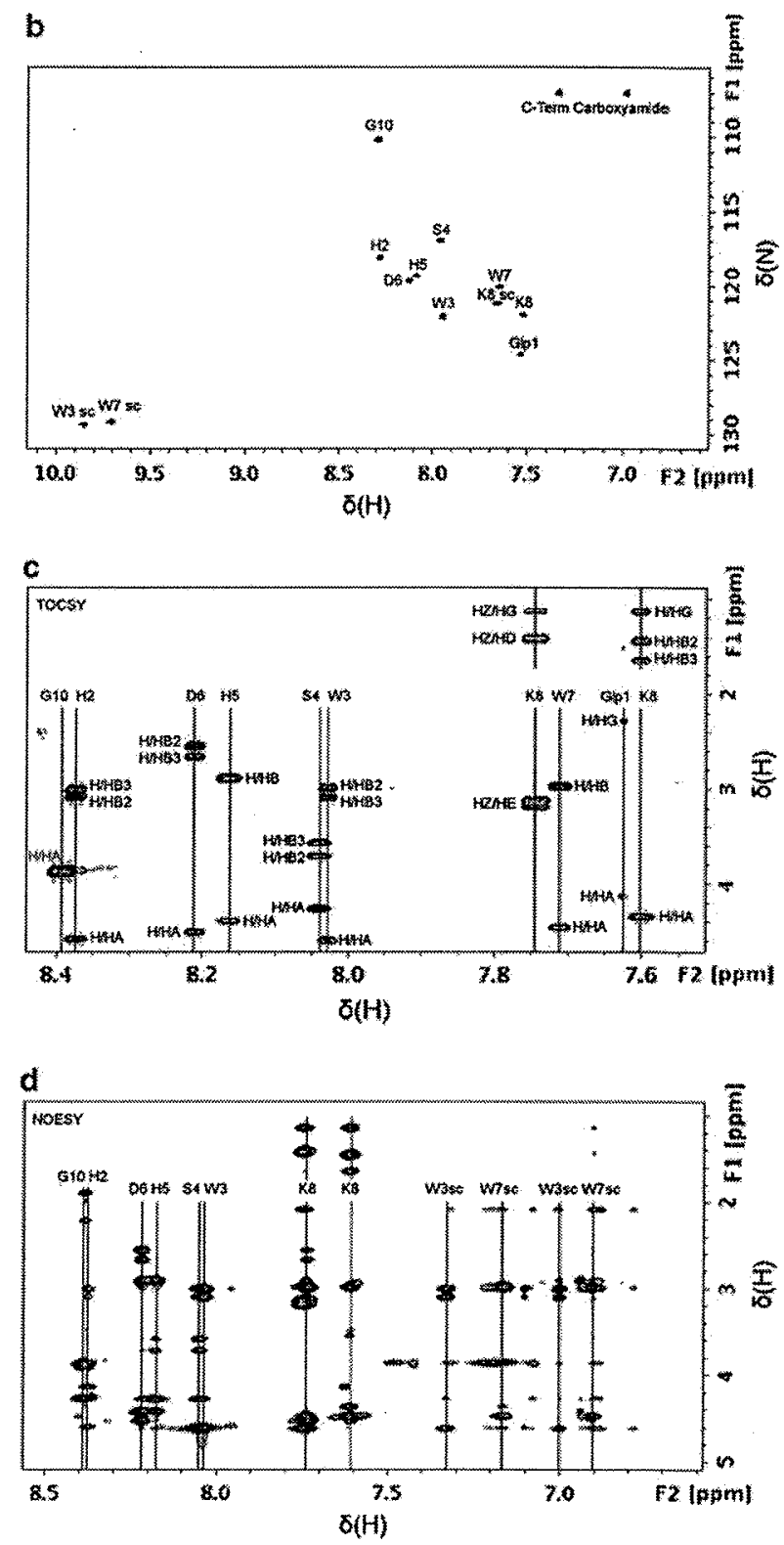

activity was lower than that of free Dau, results that could be explained by the lower cellular uptake of the bioconjugates, the lack of free drug release and by different DNAbinding properties of the resulted metabolites. 
When considering all these data, we conclude that (1) the C-13 keto group of daunorubicin can be used for the conjugation with various targeting moieties without leading to the loss of the antitumor effect and (2) the incorporation of a peptide spacer between Dau and GnRH-III is not required for the antitumor activity of the bioconjugates.

Based on the results obtained in this study, the in vivo antitumor activity of only GnRH-III(Dau=Aoa) and GnRHIII(Dau=Aoa-GFLG) bioconjugates is currently evaluated on colon carcinoma bearing mice.

Acknowledgments This work was supported by Grants from the University of Konstanz (Zukunftskolleg, Project $879 / 08$ and AFF, Project 836/09), the Hungarian National Science Fund (OTKA NK 77485) and GVOP-3.2.1.-2004-04-0005/3. The authors thank the ChemAxon Kft. (Budapest, Hungary) for the MarvinSketch Version 5.2 software.

\section{References}

Bai KB, Láng O, Orbán E, Szabó R, Köhidai L, Hudecz F, Mező G (2008) Design, synthesis, and in vitro activity of novel drug delivery systems containing tuftsin derivatives and methotrexate. Bioconjug Chem 19:2260-2269

Bajusz S, Janáky T, Csernus VJ, Bokser L, Fekete M, Srkalovic G, Redding TW, Schally AV (1989) Highly potent metallopeptide analogues of luteinizing hormone-releasing hormone. Proc Natl Acad Sci USA 86:6313-6317

Barcelo F, Martorell J, Gavilanes F, Gonzalez-Ros JM (1988) Equilibrium binding of daunomycin and adriamycin to calf thymus DNA. Temperature and ionic strength dependence of thermodynamic parameters. Biochem Pharmacol 37:2133-2138

Bax A, Davis DG (1985) MLEV-17-based two-dimensional homonuclear magnetization transfer spectroscopy. J Magn Reson 65:355-360

Braslawsky GR, Kadow K, Knipe J, McGoff K, Edson M, Kaneko T, Greenfields RS (1991) Adriamycin(hydrazone)-antibody conjugates require internalization and intracellular acid hydrolysis for antitumor activity. Cancer Immunol Immunother 33:367 -374

Buré C, Levièvre D, Delmas A (2000) Identification of by-products from an orthogonal peptide ligation by oxime bonds using mass spectrometry and tandem mass spectrometry. Rapid Commun Mass Spectrom 14:2158-2164

Chaires JB (1990) Biophysical chemistry of the daunomycin-DNA interaction. Biophys Chem 35:191-202

Chaires JB, Dattagupta N, Crothers DM (1982) Studies on interaction of anthracycline antibiotics and deoxyribonucleic acid: equilibrium binding studies on interaction of daunomycin with deoxyribonucleic acid. Biochemistry 21:3933-3940

Collins SJ, Gallo RC, Gallagher RE (1977) Continuous growth and differentiation of human myeloid leukaemic cells in suspension culture. Nature 270:347-349

David A, Kopeckova P, Minko T, Rubinstein A, Kopecek J (2004) Design of a multivalent galactoside ligand for selective targeting of HPMA copolymer-doxorubicin conjugates to human colon cancer cells. Eur J Cancer 40:148-157

Dubowchik GM, Firestone RA (1998) Cathepsin B-sensitive dipeptide prodrugs. 2. Models of anticancer drugs paclitaxel (Taxol) mitomycin $\mathrm{C}$ and doxorubicin. Bioorg Med Chem Lett $8: 3341-3346$
Dubowchik GM, Walker MA (1999) Receptor-mediated and enzymedependent targeting of cytotoxic anticancer drugs. Pharmacol Ther 83:67-123

Dubowchik GM, Firestone RA, Padilla L, Willner D, Hofstead SJ, Mosure K, Knipe JO, Lasch SJ, Trail PA (2002) Cathepsin B-labile dipeptide linkers for lysosomal release of doxorubicin from internalizing immunoconjugates: model studies of enzymatic drug release and antigen-specific in vitro anticancer activity. Bioconjug Chem 13:855-869

Etrych T, Jelínková M, Ríhová B, Ulbrich K (2001) New HPMA copolymers containing doxorubicin bound via $\mathrm{pH}$-sensitive linkage: synthesis and preliminary in vitro and in vivo biological properties. J Control Release 73:89-102

Gilladoga AC, Manuel C, Tan CT, Wollner N, Sternberg SS, Murphy ML (1976) The cardiotoxicity of adriamycin and daunomycin in children. Cancer 37:1070-1078

Graves DE, Krugh TR (1983) Adriamycin and daunorubicin bind in a cooperative manner to deoxyribonucleic acid. Biochemistry 22:3941-3947

Herédi-Szabó K, Lubke J, Tóth G, Murphy RF, Lovas S (2005) Importance of the central region of lamprey gonadotropinreleasing hormone III in the inhibition of breast cancer cell growth. Peptides 26:419-422

Herédi-Szabó K, Murphy RF, Lovas S (2006) Different signal response to lamprey GnRH-III in human cancer cells. Int J Pept Res Ther 12:359-364

Hwang T-L, Shaka AJ (1995) Water suppression that works. Excitation sculpting using arbitrary waveforms and pulsed field gradients. J Magn Reson Ser A 112:275-279

Jaracz S, Chen J, Kuznetsova LV, Ojima I (2005) Recent advances in tumor-targeting anticancer drug conjugates. Bioorg Med Chem 13:5043-5450

Keller R (2004) The computer aided resonance assignment tutorial, Ist edn. Cantina Verlag

Kim BS, Moon SS, Hwang BK (2000) Structure elucidation and antifungal activity of an anthracycline antibiotic, daunomycin, isolated from Sctinomadura roseola. J Agric Food Chem 48:1875-1881

Kovács M, Vincze B, Horváth JE, Seprődi J (2007) Structure-activity study on the LH- and FSH-releasing and anticancer effects of gonadotropin-releasing hormone (GnRH)-III analogs. Peptides $28: 821-829$

Kovács M, Szepesházi K, Schally AV (2009) Endocrine and antineoplastic effects ofantagonistic and cytotoxic analogs of luteinising hormone-releasing hormone. In: Kovács M, Merchenhalter I (eds) Neuropeptides and peptide analogs. Research Signpost, Kerela, India, pp 33-57

Krohn K (2008) Interaction of natural and synthetic anthracyclines with DNA. Curr Bioact Compounds 4:175-188

Luo Y, Bernshaw NJ, Lu ZR, Kopecek J, Prestwich GD (2002) Targeted delivery of doxorubicin by HPMA copolymer-hyaluronan bioconjugates. Pharm Res 19:396-402

Malugin A, Kopecková P, Kopecek J (2007) Liberation of doxorubicin from HPMA copolymer conjugate is essential for the induction of cell cycle arrest and nuclear fragmentation in ovarian carcinoma cells. J Control Release 124:6-10

McGhee JD, Von Hippel PH (1974) Theoretical aspects of DNA protein interactions: cooperative and non cooperative binding of large ligands to a one dimensional homogeneous lattice. J Mol Biol 86:469-489

Ménard R, Carmona E, Plouffe C, Brömme D, Konishi Y, Lefebvre J, Storer AC (1993) The specificity of the S1' subsite of cysteine proteases. FEBS Lett 328:107-110

Mezö G, Manea M (2010) Receptor-mediated tumor targeting based on peptide hormones. Expert Opin Drug Deliv 7:79-96

Mező I, Lovas S, Pályi I, Vincze B, Kálnay A, Turi G, Vadász Zs, Seprödi J, Idei M, Tóth G, Gulyás É, Ötvös F, Mák M, Horváth 
JE, Teplán I, Murphy RF (1997) Synthesis of gonadotropinreleasing hormone III analogs. Structure-antitumor activity relationships. J Med Chem 40:3353-3358

Mező G, Czajlik A, Manea M, Jakab A, Farkas V, Majer Z, Vass E Bodor A, Kapuvári B, Boldizsár M, Vincze B, Csuka O, Perczel A, Przybylski M, Hudecz F (2007) Structure, enzymatic stability and antitumor activity of sea lamprey GnRH-III and its dimer derivatives. Peptides 28:806-820

Mezö G, Manea M, Szabó I, Vincze B, Kovács M (2008) New derivatives of $\mathrm{GnRH}$ as potential anticancer therapeutic agents. Curr Med Chem 15:2366-2379

Mező G, Szabó I, Kertész I, Hegedüs R, Orbán E, Leurs U, Bösze S, Halmos G, Manea M (2010) Efficient synthesis of an (aminooxy)acetyled somatostatin derivative using (aminooxy)acetic acid as a "carbonyl capture" reagent. J Pept Sci. doi:10.1002/psc.1294

Minotti G, Cavaliere AF, Mordente A, Rossi M, Schiavello R, Zamparelli M, Possati G-F (1995) Secondary alcohol metabolites mediate iron delocalization in cytosolic fractions of myocardial biopsies exposed to anticancer anthracyclines. Novel linkage between anthracycline metabolism and iron-induced cardiotoxicity. J Clin Invest 95:1595-1605

Nagy A, Schally AV, Armatis P, Szepesházi K, Halmos G, Kovács M, Zarándi $M$, Groot K, Miyazaka M, Jungwirth A, Horváth J (1996) Cytotoxic analogs of luteinizing hormone-releasing hormone containing doxorubicin or 2-pyrrolinodoxorubicin, a derivative 500-1000 times more potent. Proc Natl Acad Sci USA 93:7269-7273

Nagy A, Plonowski A, Schally AV (2000) Stability of cytotoxic luteinizing hormone-releasing hormone conjugate (AN-152) containing doxorubicin 14-O-hemiglutarate in mouse and human serum in vitro: implications for the design of preclinical studies. Proc Natl Acad Sci USA 97:829-834

Omelyanenko V, Gentry C, Kopecková P, Kopecek J (1998) HPMA copolymer-anticancer drug-OV-TL16 antibody conjugates. II. Processing in epithelial ovarian carcinoma cells in vitro. Int $\mathrm{J}$ Cancer 75:600-608

Pályi I, Vincze B, Lovas S, Mező I, Pató J, Kálnai A, Túri G, Gaál D, Mihalik R, Péter I, Teplán I, Murphy RF (1999) Gonadotropinreleasing hormone analogue conjugates with strong selective antitumor activity. Proc Natl Acad Sci USA 96:2361-2366

Parthiban P, Balasubramanian S, Adrioss G, Kabilan S (2008) Synthesis and NMR spectral studies of some 2,6-diarylpiperidin-4-one
O-benzyloximes. Spectrochim Acta A Mol Biomol Spectrosc 70:11-24

Schally AV, Nagy A (2003) New approaches to treatment of various cancers based on cytotoxic analogs of LHRH, somatostatin and bombesin. Life Sci 72:2305-2320

Schally AV, Nagy A (2004) Chemotherapy targeted to cancers through tumoral hormone receptors. Trends Endocrinol Metab $15: 300-310$

Shao J, Tam JP (1995) Unprotected peptides as building blocks for the synthesis of peptide dendrimers with oxime, hydrazone, and thiazolidine linkages. J Am Chem Soc 117:3893-3899

Sibrian-Vazquez M, Jensen TJ, Vicente MG (2008) Synthesis, characterization, and metabolic stability of porphyrin-peptide conjugates bearing bifunctional signaling sequences. $\mathrm{J}$ Med Chem 51:2915-2923

Singh Y, Palombo M, Sinko PJ (2008) Recent trends in targeted anticancer prodrug and conjugate design. Curr Med Chem 15:1802-1826

Sower SA, Chiang Y-C, Lovas S, Conlon JM (1993) Primary structure and biological activity of a third gonadotropin-releasing hormone from lamprey brain. Endocrinology 132:1125-1131

Szabó I, Manea M, Orbán E, Csámpai A, Bősze S, Szabó R, Tejeda M, Gaál D, Kapuvári B, Przybylski M, Hudecz F, Mező G (2009) Development of an oxime bond containing daunorubicingonadotropin-releasing hormone-III conjugate as a potential anticancer drug. Bioconjug Chem 20:656-665

Taralp A, Kaplan H, Sytwu II, Vlattas I, Bohacek R, Knap AK, Hirama T, Huber CP, Hasnain S (1995) Characterization of the S3 subsite specificity of cathepsin B. J Biol Chem 270:1803618043

Trail PA, King HD, Dubowchik GW (2003) Monoclonal antibody drug immunoconjugates for targeted treatment of cancer. Cancer Immunol Immunother 52:328-337

Valentini L, Nicolella V, Vannini E (1985) Association of anthracycline derivatives with DNA: a fluorescence study. Farmaco Sci 40:377-390

Yadav AK, Mishra P, Agrawal GP (2008) An insight on hyaluronic acid in drug targeting and drug delivery. $J$ Drug Target 16:91-107

Yamazaki N, Kojima S, Bovin NV, Andre S, Gabius S, Gabius HJ (2000) Endogenous lectins as targets for drug delivery. Adv Drug Deliv Rev 43:225-244 